\title{
EVALUATION OF SOLIDS CARRYING CAPACITY IN AERATED FLUID DRILLING: REAL SCALE TESTS AND MODELING
}

\author{
A. L. Martins, \\ A. M. F. Lourenço, \\ P. H. Andrade Jr., V. Silva Jr., P. \\ R.C. Silva and E. Y. Nakagawa \\ PETROBRAS / CENPES \\ Av. Washington Soares, 1321 \\ Bairro Edson Queiroz \\ 60811-905, Fortaleza, Ceará, Brasil \\ pimenta@unifor.br

\begin{abstract}
This paper summarizes the results of two sets of experimental tests performed at PETROBRAS real scale test facility aiming the evaluation of solids return times in aerated fluid drilling. The effect of the following parameters was studied: liquid and gas injection rates, particle diameter and depth. Results indicate that the gas has a major effect in accelerating the liquid phase, which would be responsible for carrying the particles to the surface. The concept of effective liquid velocity coupled with an adequate procedure for particle sedimentation velocity calculation reproduced the experimental results adequately.
\end{abstract}

\section{INTRODUCTION}

Optimizing gas and liquid flow rates in light weight fluid drilling design is a complex task which involves knowledge on two phase flow hydraulics. A lot of effort has been spent in the prediction of the impact of gas and liquid flow rates on bottomhole ECDs (Rommetveit et al. 1995).

Of course, several combinations of liquid and gas flow rates will result in the desired ECD in the bottom. The decision of which values to use will depend on downhole motor requirements and hole cleaning criteria. This parameters will define the operational window to work while drilling a certain well.

Suppliers generally specify the required minimum and maximum liquid flow rates for feeding down hole motors. Very little is known about the flow rate requirements for adequate hole cleaning using aerated fluids. Guo et al. (1993) proposed a simplified model for liquid gas flow rate prediction which would provide a given solids concentration in the annulus. Adewumi et al. (1989) performed pilot scale experimental studies for air/solids flow.

Very few has been done up to now in investigating hole cleaning in light weight fluid drilling. Scaling down techniques seem limited in representing adequately the phenomena involved in the three phase flow. Primary field experience indicates that fluid effective velocities of 120 and $150 \mathrm{ft} / \mathrm{min}$ would clean vertical and directional wells, respectively.

The minimum velocity requirements for hole cleaning would of course depend on several aspects, including fluid and solids properties, wellpath, etc. Consequently, in many cases, the velocities normally used in the field may be much greater than necessary, resulting in high drilling costs.

This was the motivation for the development of an experimental program on PETROBRAS real scale test facility, aiming the determination of solids return time for different conditions.
The main objectives of the present study were the determination of the mechanisms which govern solids removal by aerated fluids in vertical wells and the proposal of a methodology to predict solids return time and hole cleaning requirements for a drilling operation.

The following variables were considered in this study:

$\circ \quad$ Depth
$\circ \quad$ Liquid and gas Flow Rates
$\circ \quad$ Particle Diameter

Well Description and Upgrade Instrumentation

A schematic of well 9-PE-2-TQ-BA is shown in Fig. 1. The data acquisition system interface and disposition of new equipment and surface sensors can also be seen in this figure.

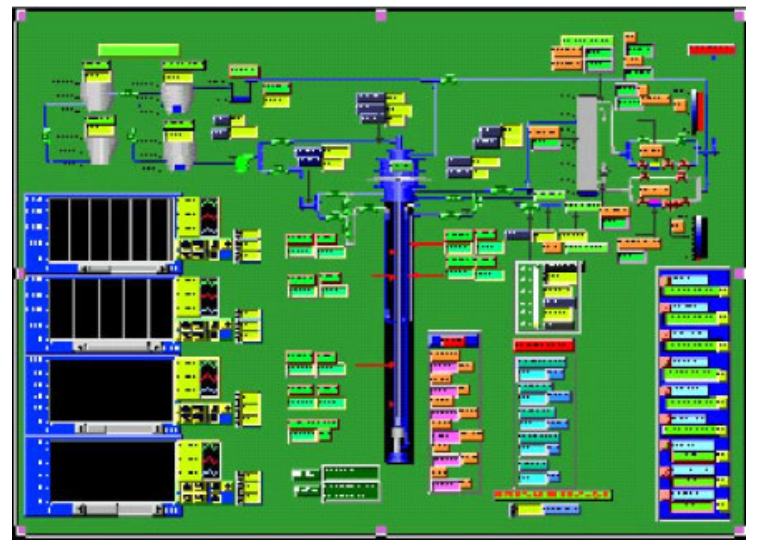

Figure 1. Data Acquisition System and Surface Instrumentation of Well 9-PE- 2-TQ-BA. 
- General Data For Well 9-PE-2-TQ-BA. The well was cased with $133 / 8$ ", casing to $1300 \mathrm{~m}$. The bottom hole static temperature is approximately $60{ }^{\circ} \mathrm{C}$. Inside this casing, a 7', (ID $=6,276^{\prime \prime}$ ) casing was set which represents the walls of the well to be simulated. The drill string consists of $3 \frac{1}{2}$ "' drill pipe (ID $=2,992$ "').

- Instrumentation. Table 1 lists the name and symbol for the different variables measured by different instruments at the surface. The working range for each sensor is also listed $\mathrm{N}_{2}$ and air flow rates are provided by the service company along with pressure and temperature. The injection of liquid was provided by triplex pumps. Seven online sensors, measuring pressure and temperature at several different elevations in the annulus between the drill string and the 7" casing were available. A logging unit recorded pressure, temperature and density data at bottom hole.

The data acquisition system was programmed on a digital microcomputer (PC) and data were recorded in ASCII format. All the measurements were available online with the tests at the program screen. The program can also control some valves at bottom hole and at the separator. The down hole data were collected and recorded in the same format by the logging unit.

Table 1. Range of Monitored Parameters

\begin{tabular}{|c|c|c|}
\hline VARIABLE & SYMBOL & CALIBRATION \\
\hline Stand Pipe Pressure & $\mathrm{P}_{\text {liq }}$ & 0 to $4000 \mathrm{psi}$ \\
\hline Kill line Pressure & $\mathrm{P}_{\mathrm{k}}$ & 0 to $4000 \mathrm{psi}$ \\
\hline Choke line Pressure & $\mathrm{P}_{\mathrm{c}}$ & 0 to $3000 \mathrm{psi}$ \\
\hline Monitoring Line Pressure & $\mathrm{P}_{\text {mon }}$ & 0 to $4000 \mathrm{psi}$ \\
\hline Stand Pipe Temperature & $\mathrm{T}_{\text {liq }}$ & 0 to $100^{\circ} \mathrm{C}$ \\
\hline Kill Line Temperature & $\mathrm{T}_{\mathrm{k}}$ & 0 to $100^{\circ} \mathrm{C}$ \\
\hline Choke Line Temperature & $\mathrm{T}_{\mathrm{c}}$ & 0 to $100^{\circ} \mathrm{C}$ \\
\hline Level of Tank 1 & $\mathrm{Tq}_{2, \mathrm{Us}}$ & 0 to $86 \mathrm{bbl}$ \\
\hline Level of Tank 2 & $\mathrm{Tq} 1$ & 0 to $155 \mathrm{bbl}$ \\
\hline Level of Tank 3 & $\mathrm{Tq} 2$ & 0 to $50 \mathrm{bbl}$ \\
\hline
\end{tabular}

\section{Solids Transport Experiments}

Two sets of experiments were carried on with the purpose of determining the solids return time while drilling a vertical well with aerated fluids. Set number 1 aimed the investigation of the effect of gas and liquid injection rates and particle diameter in the return time of solids carried by nitrogen - water mixtures. Set number 2 aimed the gathering of additional data besides the investigation of additional effects, such as well depth and nature of gas phase (air - water mixtures were injected in set 2 tests).

In both sets of experiments performed, the drill column was used without a float valve in order to allow the use of the logging unit. All tests were run with no pipe rotation.

- Wellbore Configuration. A schematic of the wellbore configuration used for the cuttings transport experiments is shown in Fig. 2. Gas and liquid were injected through the drill pipe as in conventional drilling operations. A bridge-plug was set at $700 \mathrm{~m}$ (set 1) and $1270 \mathrm{~m}$ (set 2) to isolate the bottom portion of the well. The Figure also shows the position of the online pressure and temperatures sensors in the annulus.

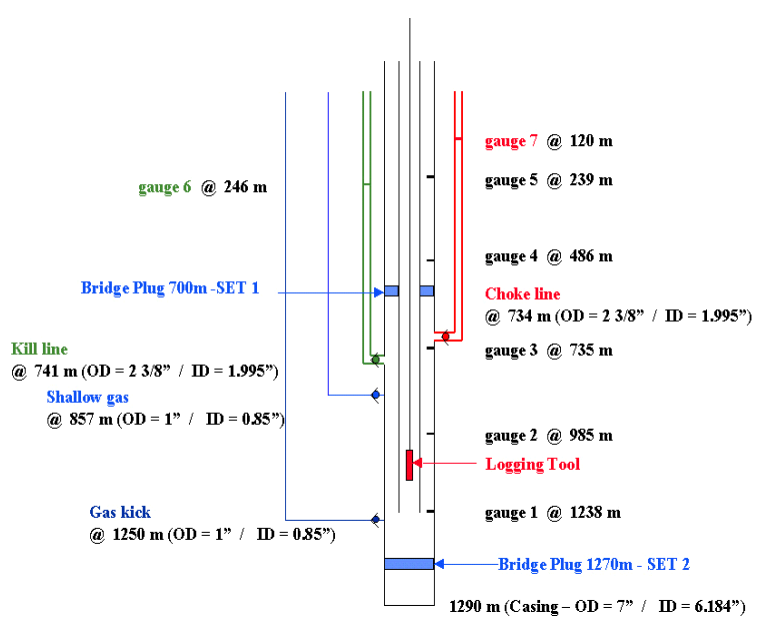

Figure 2. Wellbore Configuration For Cuttings Transport Experiments general Data For Well 9-PE-2-TQ-BA

- Additional Instruments.

- Solids Return Monitor. The Solids Monitor works on the principle that when a fluid containing solid particles flows through a $90^{\circ}$ curve, the solid particles, if heavier than the fluid, will be thrown to the wall having the largest radius. The particles that hit the wall, produce a sound that can be detected by a sonic sensor installed on the outside of the pipe, close to the curve. The intensity of the sound is proportional to the particle concentration.

The monitor is an external, non-intrusive equipment that is able to identify and quantify the presence of sand in the flux of oil, gas, water or multiphase fluids containing these components.

- Viewing Window. A one meter long acrylic pipe with a 7" OD was specially designed for these tests to withstand 300 psi and installed at the separator line.

The function of this pipe was to visually identify solids return in real time and to check the solid, gas and liquid flow patterns. The acrylic pipe was installed as close as possible to the Sand Monitors, as illustrated in Fig. 3, in order to confirm solids return time results. In Fig. 4, it can be seen that a bed of solids has formed on the bottom of the acrylic pipe for the experiment where no gas was injected, while for high gas flow rates, annular gas flow develops as seen in Fig. 5.

During the second phase tests, the viewing window was suppressed because of installations problems and no available time for manufacturing another one.

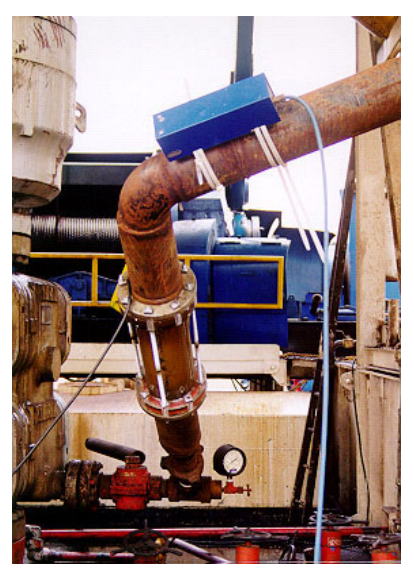

Figure 3. Relative positions of the acrylic pipe and the SAM 400 sensor. 


\section{TECNOLOGIA/TECHNOLOGY}

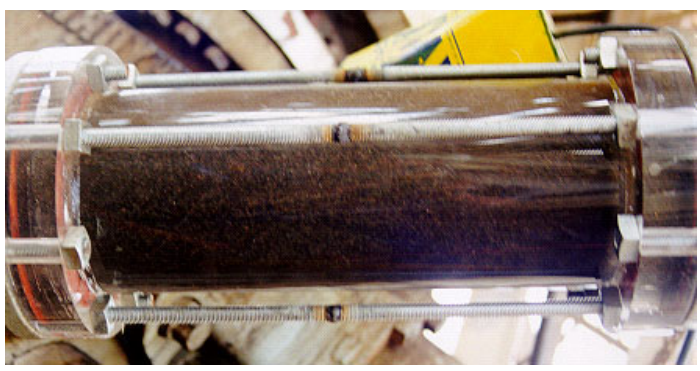

Figure 4. Solids Bed Formation - Low Gas Flow Rates

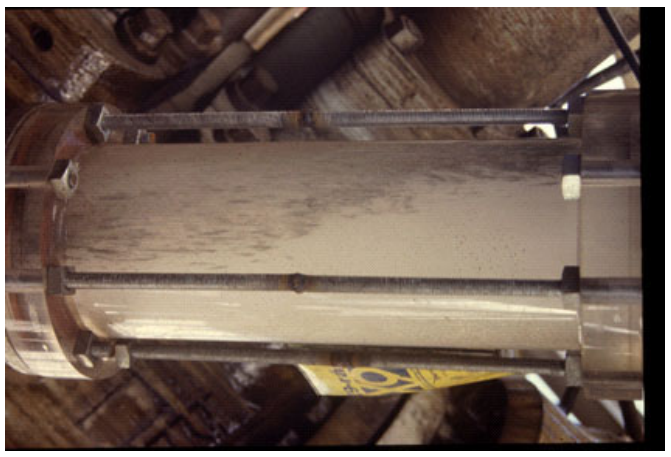

Figure 5. Annular Flow Pattern - High Gas Flow Rates

Test Procedure And Preliminary Activities

- Coloured Particles. To make visualization in the acrylic pipe easier, $50 \%$ of the sand was painted in different colors, using an oil-based paint. This colored sand was to act as a tracer. After several trial tests at Petrobras' R\&D Center labs, the best colors and paint type for these tests were chosen.

- Test Procedure For Set 1. The procedure followed for each solids return test is outlined below:

- $400 \mathrm{lbs}$ of screened sand was injected through the annulus, alternating portions of white and colored particles in Fig. 6.

- Waited the required time for all particles to settle in the bridge plug. This time was previously optimized in lab scale sedimentation tests. The arrival of solids at bottom was monitored by the logging unit cable.

- The solids monitor was tested by producing noise in the curved walls.

- Gas and liquid injection began with the drill column positioned $10 \mathrm{~m}$ above the top of the sand. Injection pressure was monitored until it stabilized, confirming steady-state flow in the well.

- The drill string was lowered as fast as possible to the top of the sand. The start and end times were registered.

- Solids return was observed in the acrylic pipe, on a screen and monitored by Monitor 1 through the computer coupled to the data acquisition system.

- The drill string was lowered again for 3 more meters, in order to observe a new peak of solids return. This step was introduced midway through the set of experiments, as a way to confirm results.

- Three samples of sand were collected for grain size evaluation

- Test Procedure For Set 2. In these tests, the acrylic view window was suppressed because of installation problems. In spite of that, the sand monitoring systems had good qualitative performance, allowing solids return time prediction with good precision.

\section{A. L. Martins et al. Evaluation of Solids Carrying...}

The final procedure that was used at the majority of the tests is described below.

- $400 \mathrm{lb}$ of screened sand was injected and pumped through the drillpipe, helped by the continuous up and down movement of the logging bottom hole tool.

- After sand injection, all the necessary connections were made and the particles were pumped with the test fluid till the bottom of the hole.

- The Sand monitor was tested by producing noise in the curved walls.

- Gas and liquid injection began with the drill column positioned $10 \mathrm{~m}$ above the top of the sand. Injection pressure was monitored until it stabilized, confirming steady-state flow in the well.

- The drill string was lowered as fast as possible, to the top of the sand. The start and end times were registered.

- Solids return were monitored by 2 equipments through the computers coupled to the data acquisition systems.

- The drill string was lowered again till top of sand, in order to observe a new peak of solids return. This step represents a repetition of the test.

Table 2. Test Matrix for SET $1-700 \mathrm{~m}$.

\begin{tabular}{|c|c|c|c|}
\hline TEST & $\begin{array}{c}\text { PARTICLE } \\
\text { DIAMETER } \\
(\mathrm{mm})\end{array}$ & $\begin{array}{c}\text { LIQUID FLOW RATE } \\
(\mathrm{GPM})\end{array}$ & $\begin{array}{c}\text { GAS FLOW } \\
\text { RATE } \\
(\text { SCFM })\end{array}$ \\
\hline 1.1 & $1.4(\mathrm{D} 1)$ & 60 & 0 \\
\hline 1.2 & $1.4(\mathrm{D} 1)$ & 100 & 0 \\
\hline 1.3 & $1.4(\mathrm{D} 1)$ & 60 & 300 \\
\hline 1.4 & $1.4(\mathrm{D} 1)$ & 100 & 300 \\
\hline 1.5 & $5.78(\mathrm{D} 2)$ & 100 & 300 \\
\hline 1.6 & $1.4(\mathrm{D} 1)$ & 60 & 500 \\
\hline 1.7 & $1.4(\mathrm{D} 1)$ & 100 & 500 \\
\hline 1.8 & $5.78(\mathrm{D} 2)$ & 100 & 700 \\
\hline 1.9 & $1.4(\mathrm{D} 1)$ & 60 & 700 \\
\hline 1.10 & $1.4(\mathrm{D} 1)$ & 100 & 700 \\
\hline 1.11 & $5.78(\mathrm{D} 2)$ & 100 & 1000 \\
\hline 1.12 & $1.4(\mathrm{D} 1)$ & 100 & 1000 \\
\hline
\end{tabular}

Note: In these tests, $800 \mathrm{lb}$ was injected in the well to provide higher amount of sand at bottom hole. Performing this way, two consecutives tests could be done with minimum waiting time.

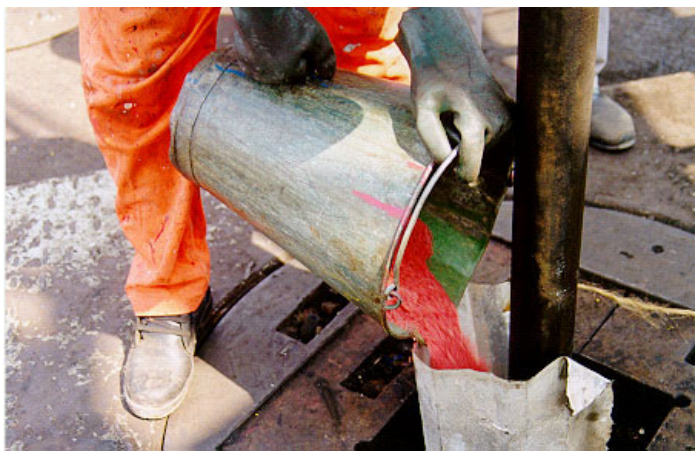

Figure 6. Injection of Colored Sand 


\section{TECNOLOGIA/TECHNOLOGY}

Table 3. Test Matrix for SET $2-1270 \mathrm{~m}$.

\begin{tabular}{|c|c|c|c|}
\hline TEST & $\begin{array}{c}\text { PARTICLE } \\
\text { DIAMETER } \\
(\mathrm{mm})\end{array}$ & $\begin{array}{c}\text { LIQUID } \\
\text { FLOW RATE } \\
(\mathrm{GPM})\end{array}$ & $\begin{array}{c}\text { GAS FLOW } \\
\text { RATE (SCFM) }\end{array}$ \\
\hline 2.8 & $1.4(\mathrm{D} 1)$ & 100 & 300 \\
\hline 2.9 & $1.4(\mathrm{D} 1)$ & 100 & 700 \\
\hline 2.10 & $1.4(\mathrm{D} 1)$ & 60 & 400 \\
\hline 2.11 & $1.4(\mathrm{D} 1)$ & 60 & 1000 \\
\hline 2.12 & $1.4(\mathrm{D} 1)$ & 100 & 500 \\
\hline 2.13 & $1.4(\mathrm{D} 1)$ & 100 & 1000 \\
\hline 2.14 & $1.4(\mathrm{D} 1)$ & 100 & 700 \\
\hline 2.15 & $1.4(\mathrm{D} 1)$ & 100 & 1000 \\
\hline
\end{tabular}

- Test Matrix for Set 1. A matrix for the first tests was proposed based on solids return prediction for several liquid flow rates. Gas flow rates were set based on previous real scale two phase flow tests performed in the same facilities. The gas and liquid rates were chosen to cover a wide range of flow rates without resulting in high return pressures, which would make the use of the acrylic window impossible. Nitrogen was used as the gas phase, where as water was used as liquid phase. Table 2 summarizes these tests

- Test Matrix for Set 2. A test matrix was proposed based on the range of set 1 tests gas and liquid flow rates. Eight tests were suggested contemplating repetition of gas and liquid flow rates at the new depth $(1270 \mathrm{~m})$, new flow rates to simulate similar fluid velocities and qualities to the $700 \mathrm{~m}$ tests. Air was used as the gas phase and water as liquid phase. The performed test matrix is shown in Table 3.

\section{Basic Definitions}

- Sedimentation Velocity and Transport Velocity of Particles. A very important concept in the study of solids transport in vertical wells is the particle sedimentation velocity when calculated for the flow geometry. The major factors influencing the sedimentation velocity are:

- particle properties: shape, size and density;

- fluid properties: rheology and density;

- geometry ( infinite or confined medium).

A classical mathematical development for the problem, considering the creeping flow of a sphere in a Newtonian fluid in infinite medium, is the well known Stokes Law. This idealized situation, however, does not represent adequately most practical cases.

In order to overcome this lack of information, several research works have been developed aiming the quantification of cuttings sedimentation velocities. The main techniques applied are the observation of sedimentation time and the fluidization approach.

Based on fluidization experiments, Sá et al. (1996) developed a correlation for the implicit prediction of sedimentation velocities of irregularly shaped particles in annular flow of Newtonian or non-Newtonian fluids considering wall and population effects.
A. L. Martins et al. Evaluation of Solids Carrying...

$$
\mathrm{C}_{\mathrm{D}}=\left[\left(\frac{24}{\operatorname{Re}_{*}}\right)^{m}+\left(\frac{103,3}{\mathrm{e}^{5,441 \psi}}\right)^{m}\right]^{1 / m} ; 0,4 \leq \psi \leq 1,0
$$

where:

$$
\mathrm{C}_{\mathrm{D}}=\frac{4}{3} \frac{\mathrm{d}_{\mathrm{p}} g}{\mathrm{v}_{\infty}} \frac{\left(\rho_{\mathrm{p}}-\rho_{\mathrm{f}}\right)}{\rho_{\mathrm{f}}}
$$

and

$$
\begin{aligned}
& \mathrm{m}=0.9779-0.1557 \psi \\
& \operatorname{Re}_{*}=\frac{\mathrm{V}_{\infty}^{2} \rho_{\mathrm{f}}}{\tau}
\end{aligned}
$$

where: $V_{w}$ is the sedimentation velocity considering wall effects, $D_{h}$ is the hydraulic diameter defined by 0,816 (annular external diameter - annular internal diameter ), $d_{p}$ is the particle diameter, $R e$ is the Reynolds number based on $\mathrm{V}_{\mathrm{w}}, \mathrm{v}_{\infty}$ is defined as the sedimentation velocity of an irregularly shaped particle in an infinite medium and is sphericity.

The sedimentation velocity of an irregular particle in an infinite medium can be estimated from experiments of sedimentation time. Particle diameter and density were evaluated by picnometric tests. The particle diameter considered is the diameter of the sphere with the same volume than the particle:

$$
d_{s}=\sqrt[3]{\frac{6 V_{s}}{\pi}}
$$

The population effect can be estimated by:

$$
\frac{V p}{V w}=\varepsilon_{\text {and }}^{s} \quad s=\left(3,44+2,66 \frac{d p}{D h}\right) \operatorname{Re}^{-0,082}
$$

where $v_{p}$ is the particle's fall velocity considering population effects, $\mathrm{V}_{\mathrm{w}}$ is the sedimentation velocity considering wall effects, Re is the Reynolds number based on $\mathrm{V}_{\mathrm{w}}$ and $\varepsilon$ is the cuttings bed porosity, defined as:

$$
\varepsilon=1-\text { volumetric concentration of solids }
$$

During fluid circulation, solids will ascend through the annulus with a transport velocity, $V_{t}$, as illustrated in Fig. 7.

$$
V_{t}=V_{f}-V_{S}
$$

where:

$\mathrm{V}_{\mathrm{f}}=$ average fluid velocity in the annulus and

$\mathrm{V}_{\mathrm{S}}=$ particle sedimentation velocity

A transport ratio, RT, can be defined as:

$$
R T=\frac{V_{t}}{V_{f}}
$$




\section{TECNOLOGIA/TECHNOLOGY}

The annular fluid velocity and the transport ratio are generally used for cuttings transport evaluation in drilling vertical and inclined wells. Field studies indicate that RT values above $25 \%$ help avoid operational problems and minimum annular fluid velocities of $120 \mathrm{ft} / \mathrm{min}$ are recommended. Naturally, these values depend on several parameters such as the fluid carrying capacity and that drilling phase's well diameter.

- Flow Velocites In The Well. The objective now became to develop a similar method to the one described above, to represent fluid ascension velocity and to identify the influence of each phase (liquid and gas) on solids transport when using aerated fluids. Due to the presence of gas, the velocities of the liquid and gas phases will vary with pressure and temperature, and consequently with depth.

There are different methods of calculating the annular fluid velocity, $\mathrm{V}_{f}$, which will be used in Eq. 9 to calculate the solids transport velocity, $\mathrm{V}_{t}$. The definitions of variables which are commonly used in the analysis of gas-liquid flows are the following:

- Mixture Velocity. In this case the gas and liquid phases are considered to be a homogeneous fluid. The mixture velocity is defined as the sum of gas and liquid velocities if each were flowing alone in the annulus, according to Eq. 11. The gas velocity is corrected for pressure and temperature changes along the well.

$$
V_{M I X T U R E}=\frac{\left(Q_{L I Q}+Q_{G A S}\right)}{A_{A N N U L U S}}
$$

where:

$$
A_{A N N U L U S}=\pi \frac{\left(D_{E X T}{ }^{2}-D_{I N T}^{2}\right)}{4}
$$

The liquid is considered incompressible and gas flow rate is corrected by the pressure and temperature changes along the well. This hypothesis states the non-slip condition between gas and liquid, assumes that the liquid gas mixture flows as a homogeneous fluid through the well.

- Effective Liquid Velocity. Liquid velocity is defined as the ratio between liquid flow rate and the area effectively occupied by it in an annulus cross section, according to:

$$
V_{E F F}=\frac{Q_{L I Q}}{\text { Liquid Effective Area }}
$$

where:

$$
\text { Liquid.Effective.Area }=(1-\alpha) * A_{\text {ANNULUS }}
$$

And where $\alpha$ is the fraction of the annular space occupied by the gas in the mixture at each cross section.

If slip occurs between the gas and liquid phases, the gas fraction, $\alpha$, must be considered. Slip between the phases means that the gas 'slips' from the fluid as it expands, creating a relative velocity between the two phases. If $\alpha$ is calculated based on the no-slip model, Eq. 13 coincides with the mixture velocity definition. (Eq.11)

\section{Results And Discussion}

Table 4 shows the results of solids return time for each test of set 1 while Table $\mathbf{5}$ shows the results for set 2 ,

\section{A. L. Martins et al. Evaluation of Solids Carrying...}

Experimental data were obtained by the accompaniment of sand arrival in the sand monitoring equipment and in the acrylic pipe. Experimental time began to be recorded in the stripping operation and finished at the peak of solids arrival. The maximum and minimum values were obtained considering the beginning and the end of the stripping operation. In the test where more than one strip was performed, the second was considered more accurate.

- Effect of Liquid Flow Rate. Of course, liquid flow rate has a major effect on solids return time. Table 6 shows the experimental and predicted return times for the tests performed with two different liquid flow rates and the same gas flow rate. The last column represents the relative reduction in solids return time due to increase in liquid flow rate (the average between minimum and maximum experimental times was considered).

Results show that the effect is more pronounced in the lower gas flow rates tests. With the increase of gas injection rates, the fluid velocity has a smaller importance on the total velocity of the system.

- Effect of Particle Diameter. Table 7 shows the results of tests performed with water at $700 \mathrm{~m}$ (set 1) at same flow rate conditions and different particle diameters. Results indicate a minor effect of particle diameter on solids return time when drilling with high total flow rates. Some uncertainties arise from the longer stripping times verified in tests 1.8 and 1.9.

- Effect of Gas Flow Rate. Table 8 illustrates the effect of gas flow rate increase on the cuttings return time in set 1 tests. All the relative improvements are calculated from the average time values and are related to the tests with the same fluid flow rate and no gas. Results indicate that the relative improvement is bigger at the tests where $60 \mathrm{GPM}$ of liquid was pumped.

Table 9 shows the same for set 2 tests carried with water at $1270 \mathrm{~m}$. The same conclusions can be drawn also in this case: the effect of gas was more pronounced in the smaller liquid flow rate.

- Effect of Depth. Table 10 shows the calculated return velocities for tests with water performed at two different depths $(700$ and $1270 \mathrm{~m})$ and the same injection flow rates. As expected, average return velocities are higher in the $700 \mathrm{~m}$ tests, where the gas is more expanded.

\section{Analysis}

- Fall Velocity Equations. Particle diameter affects directly the sedimentation velocity of the particles, resulting in different solids return velocities when drilling with incompressible fluids. Table 11 shows fall velocity predictions according to the methodology proposed on Eqs. 1 to 10.

- Solids Return Time Prediction. In an effort to have a simple method of predicting cuttings transport using an aerated fluid, the measured cuttings return time was compared to calculated return time values. The transport velocity was calculated using Eq. 8 with the aerated fluid velocity obtained from either the mixture or the liquid velocity methods discussed before. Based on the transport velocity in each section of the well, the total return time was calculated. The mixture and liquid velocities were estimated using computer simulators available at the market. Results are shown on table 12 and 13 for sets 1 and 2 , respectively. 
TECNOLOGIA/TECHNOLOGY

Table 4. Experimental Results of Solids Return Time - SET $1-700 \mathrm{~m}$.

\begin{tabular}{|c|c|c|c|c|}
\hline TEST & $\begin{array}{c}\text { LIQUID } \\
\text { FLOW } \\
\text { RATE } \\
\text { (GPM) / } \\
\text { GAS FLOW } \\
\text { RATE } \\
\text { (SCFM) }\end{array}$ & $\begin{array}{l}\text { PARTICLE } \\
\text { DIAMETER }\end{array}$ & $\begin{array}{c}\text { MINIMUM } \\
\text { EXPERIME } \\
\text { NTAL } \\
\text { RETURN } \\
\text { TIME (min.) }\end{array}$ & $\begin{array}{c}\text { MAXIMUM } \\
\text { EXPERIME } \\
\text { NTAL } \\
\text { RETURN } \\
\text { TIME (min.) }\end{array}$ \\
\hline 1.1 & $60 / 0$ & D1 & 90 & 100 \\
\hline 1.2 & $100 / 0$ & D1 & 37 & 38 \\
\hline 1.3 & $60 / 300$ & D1 & 20,5 & 24,0 \\
\hline 1.4 & $60 / 500$ & D1 & 18,0 & 23,0 \\
\hline 1.5 & $60 / 700$ & D1 & 7,0 & 14,0 \\
\hline 1.6 & $100 / 300$ & D1 & 14,0 & 15,0 \\
\hline 1.7 & $100 / 500$ & D1 & 7,5 & 12,0 \\
\hline 1.8 & $100 / 700$ & D1 & 7,5 & 11,0 \\
\hline 1.9 & $100 / 1000$ & D1 & 5,0 & 8,0 \\
\hline 1.10 & $100 / 300$ & D2 & 15,0 & 16,0 \\
\hline 1.11 & $100 / 700$ & D2 & 8,0 & 8,5 \\
\hline 1.12 & $100 / 1000$ & D2 & 5,5 & 6,5 \\
\hline
\end{tabular}

Table 5. Experimental Results of Solids Return Time - SET $2-1270 \mathrm{~m}$.

\begin{tabular}{|c|c|c|c|c|}
\hline TEST & $\begin{array}{c}\text { LIQUID FLOW } \\
\text { RATE (GPM) } \\
\text { GAS FLOW RATE } \\
\text { (SCFM) }\end{array}$ & $\begin{array}{c}\text { PARTI } \\
\text { CLE } \\
\text { DIAM } \\
\text { ETER }\end{array}$ & $\begin{array}{c}\text { MINIMUM } \\
\text { EXPERIMENT } \\
\text { AL RETURN } \\
\text { TIME (min.) }\end{array}$ & $\begin{array}{c}\text { MAXIMUM } \\
\text { EXPERIMENTAL } \\
\text { RETURN TIME } \\
\text { (min.) }\end{array}$ \\
\hline 2.8 & $60 / 400$ & D1 & 63 & 64 \\
\hline 2.9 & $60 / 1000$ & D1 & 36 & 38 \\
\hline 2.10 & $100 / 300$ & D1 & 42 & 43 \\
\hline 2.11 & $100 / 500$ & D1 & 27 & 29 \\
\hline 2.12 & $100 / 700$ & D1 & 23 & 24 \\
\hline 2.13 & $100 / 1000$ & D1 & 18 & 19 \\
\hline 2.14 & $100 / 700$ & D1 & 27 & 29 \\
\hline 2.15 & $100 / 1000$ & D1 & 27 & 28 \\
\hline
\end{tabular}

Table 6. Effect of Liquid Flow Rate on Solids Return Time

\begin{tabular}{|c|c|c|c|c|c|}
\hline TEST & $\begin{array}{c}\text { LIQUID } \\
\text { FLOW } \\
\text { RATE } \\
\text { (GPM)/ }\end{array}$ & $\begin{array}{c}\text { PA } \\
\text { RT } \\
\text { GAS FLOW } \\
\text { RATE } \\
\text { (SCFM) }\end{array}$ & $\begin{array}{c}\text { MINIMU } \\
\text { LE } \\
\text { EXPERIM } \\
\text { ENTAL } \\
\text { RETURN } \\
\text { TIME } \\
(\mathrm{min})\end{array}$ & $\begin{array}{c}\text { MAXIMUM } \\
\text { EXPERIMENT } \\
\text { AL RETURN } \\
\text { TIME } \\
(\mathrm{min})\end{array}$ & $\begin{array}{c}\text { RELATIV } \\
\text { E } \\
\text { IMPROVE } \\
\text { MENT } \\
(\%)\end{array}$ \\
\hline 1.1 & $60 / 0$ & D1 & 90 & 100 & 61 \\
\hline 1.2 & $100 / 0$ & D1 & 37 & 38 & \\
\hline 1.3 & $60 / 300$ & D1 & 20,5 & 24,0 & 34 \\
\hline 1.6 & $100 / 300$ & D1 & 14,0 & 15,0 & \\
\hline 1.4 & $60 / 500$ & D1 & 18,0 & 23,0 & 48,5 \\
\hline 1.7 & $100 / 500$ & D1 & 7,5 & 12,0 & \\
\hline 1.5 & $60 / 700$ & D1 & 7,0 & 14,0 & 9,5 \\
\hline 1.8 & $100 / 700$ & D1 & 7,5 & 11,0 & \\
\hline
\end{tabular}

Table 7. Effect of Particle Diameter on Solids Return Time

\begin{tabular}{|c|c|c|c|c|}
\hline TEST & $\begin{array}{c}\text { LIQUID FLOW } \\
\text { RATE (GPM)/ } \\
\text { GAS FLOW } \\
\text { RATE (SCFM) }\end{array}$ & $\begin{array}{c}\text { PART } \\
\text { ICLE }\end{array}$ & $\begin{array}{c}\text { MINIMUM } \\
\text { EXPERIMEN } \\
\text { TAL RETURN } \\
\text { TIME (min) }\end{array}$ & $\begin{array}{c}\text { MAXIMUM } \\
\text { EXPERIMENT } \\
\text { AL RETURN } \\
\text { TIME (min) }\end{array}$ \\
\hline 1.6 & $100 / 300$ & D1 & 14,0 & 15,0 \\
\hline 1.10 & $100 / 300$ & D2 & 15,0 & 16,0 \\
\hline 1.8 & $100 / 700$ & D1 & 7,5 & 11,0 \\
\hline 1.11 & $100 / 700$ & D2 & 8,0 & 8,5 \\
\hline 1.9 & $100 / 1000$ & D1 & 5,0 & 8,0 \\
\hline 1.12 & $100 / 1000$ & D2 & 5,5 & 6,5 \\
\hline
\end{tabular}

\section{A. L. Martins et al. Evaluation of Solids Carrying...}

Table 8. Effect of Gas Flow Rate on Solids Return TimeSet $1-700 \mathrm{~m}$.

\begin{tabular}{|c|c|c|c|c|c|}
\hline TEST & $\begin{array}{c}\text { LIQUID } \\
\text { FLOW } \\
\text { RATE } \\
\text { (GPM)/ } \\
\text { GAS FLOW } \\
\text { RATE } \\
(\text { SCFM) }\end{array}$ & $\begin{array}{c}\text { PAR } \\
\text { TICL } \\
\text { E }\end{array}$ & $\begin{array}{c}\text { MINIMUM } \\
\text { EXPERIME } \\
\text { NTAL } \\
\text { RETURN } \\
\text { TIME } \\
(\text { min. })\end{array}$ & $\begin{array}{c}\text { MAXIMUM } \\
\text { EXPERIME } \\
\text { NTAL } \\
\text { RETURN } \\
\text { TIME } \\
(\mathrm{min} .)\end{array}$ & $\begin{array}{c}\text { RELAT } \\
\text { IVE } \\
\text { IMPRO } \\
\text { VEME } \\
\text { NT (\%) }\end{array}$ \\
\hline 1.1 & $60 / 0$ & D1 & 90 & 100 & \\
\hline 1.3 & $60 / 300$ & D1 & 20,5 & 24,0 & 77 \\
\hline 1.4 & $60 / 500$ & D1 & 18,0 & 23,0 & 78 \\
\hline 1.5 & $60 / 700$ & D1 & 7,0 & 14,0 & 89 \\
\hline 1.2 & $100 / 0$ & D1 & 37 & 38 & \\
\hline 1.6 & $100 / 300$ & D1 & 14,0 & 15,0 & 61 \\
\hline 1.7 & $100 / 500$ & D1 & 7,5 & 12,0 & 73 \\
\hline 1.8 & $100 / 700$ & D1 & 7,5 & 11,0 & 75 \\
\hline 1.9 & $100 / 1000$ & D1 & 5,0 & 8,0 & 83 \\
\hline
\end{tabular}

Table 9. Effect of Gas Flow Rate on Solids Return Time Set $2-1270 \mathrm{~m}$.

\begin{tabular}{|c|c|c|c|c|c|}
\hline TEST & $\begin{array}{c}\text { LIQUID } \\
\text { FLOW } \\
\text { RATE } \\
\text { (GPM) / } \\
\text { GAS FLOW } \\
\text { RATE } \\
\text { (SCFM) }\end{array}$ & $\begin{array}{c}\text { PAR } \\
\text { TIC } \\
\text { LE }\end{array}$ & $\begin{array}{c}\text { MINIMUM } \\
\text { EXPERIM } \\
\text { ENTAL } \\
\text { RETURN } \\
\text { TIME } \\
\text { (min.) }\end{array}$ & $\begin{array}{c}\text { MAXIMUM } \\
\text { EXPERIME } \\
\text { NTAL } \\
\text { RETURN } \\
\text { TIME } \\
\text { (min.) }\end{array}$ & $\begin{array}{l}\text { RELAT } \\
\text { IVE } \\
\text { IMPRO } \\
\text { VEME } \\
\text { NT (\%) }\end{array}$ \\
\hline & $100 / 0$ & D1 & \multicolumn{2}{|c|}{69 (estimated) } & \\
\hline 2.10 & $100 / 300$ & D1 & 42 & 43 & 38 \\
\hline 2.11 & $100 / 500$ & D1 & 27 & 29 & 59 \\
\hline 2.12 & $100 / 700$ & D1 & 23 & 24 & 66 \\
\hline 2.13 & $100 / 1000$ & D1 & 18 & 19 & 73 \\
\hline
\end{tabular}

Table 10. Effect of Depth on Solids Return Time

\begin{tabular}{|c|c|c|c|c|c|c|}
\hline TEST & $\begin{array}{c}\text { LIQUID } \\
\text { FLOW RATE } \\
\text { (GPM)/GAS } \\
\begin{array}{c}\text { FLOW RATE } \\
\text { (SCFM) })\end{array}\end{array}$ & $\begin{array}{c}\text { DEPTH } \\
(\mathrm{m})\end{array}$ & \multicolumn{2}{|c|}{$\begin{array}{c}\text { SOLIDS RETURN } \\
\text { TIME }\end{array}$} & \multicolumn{2}{|c|}{$\begin{array}{c}\text { RETURN } \\
\text { VELOCITY } \\
\text { (M/MIN) }\end{array}$} \\
\hline & & & \multicolumn{2}{|c|}{} & \multicolumn{2}{|c|}{} \\
\hline 1.6 & $100 / 300$ & 700 & 14 & 15 & 50 & 46.67 \\
\hline 1.7 & $100 / 500$ & 700 & 7.5 & 12 & 93.33 & 58.33 \\
\hline 1.8 & $100 / 700$ & 700 & 7.5 & 11 & 93.33 & 63.64 \\
\hline 1.9 & $100 / 1000$ & 700 & 5 & 8 & 140 & 87.50 \\
\hline 2.1 & $100 / 300$ & 1270 & 42 & 43 & 30.24 & 29.53 \\
\hline 2.11 & $100 / 500$ & 1270 & 27 & 29 & 47.04 & 43.79 \\
\hline 2.12 & $100 / 700$ & 1270 & 23 & 24 & 55.22 & 52.92 \\
\hline 2.13 & $100 / 1000$ & 1270 & 18 & 19 & 70.56 & 66.84 \\
\hline
\end{tabular}

Table 11. Predicted and Measured Values for Sedimentation Velocities in Water

\begin{tabular}{|c|c|c|c|c|l|}
\hline $\begin{array}{c}\text { PARTI } \\
\text { CLE }\end{array}$ & $\begin{array}{c}\text { DIAM } \\
\text { ETER } \\
(\mathrm{mm})\end{array}$ & $\begin{array}{c}\text { DENSIT } \\
\text { Y } \\
\left(\mathrm{g} / \mathrm{cm}^{3}\right)\end{array}$ & $\begin{array}{c}\text { EXPERIMENT } \\
\text { AL } \\
\text { SEDIMENTAT } \\
\text { ION } \\
\text { VELOCITY } \\
(\mathrm{V} \infty)(\mathrm{ft} / \mathrm{min})\end{array}$ & $\begin{array}{c}\text { EVALUATED } \\
\text { SEDIMENTAT } \\
\text { ION } \\
\text { VELOCITY } \\
(\mathrm{V} \infty)(\mathrm{ft} / \mathrm{min})\end{array}$ & $\begin{array}{l}\text { SEDIMENTA } \\
\text { TION } \\
\text { VELOCITY } \\
\text { WITH WALL } \\
\text { EFFECT } \\
\left(\mathrm{V}_{\mathrm{W}}\right)(\mathrm{ft} / \mathrm{min})\end{array}$ \\
\hline $\mathrm{D} 1$ & 1,4 & 2,61 & 26,5 & 28.8 & 25,7 \\
\hline $\mathrm{D} 2$ & 5,67 & 2,78 & 47,5 & 53.2 & 37,2 \\
\hline
\end{tabular}




\section{TECNOLOGIA/TECHNOLOGY}

Table 12. Experimental and Calculated Results of Solids Return Time - SET1 - 700m.

\begin{tabular}{|c|c|c|c|c|c|}
\hline TEST & $\begin{array}{c}\text { LIQUID } \\
\text { FLOW } \\
\text { RATE } \\
\text { (GPM) / } \\
\text { GAS } \\
\text { FLOW } \\
\text { RATE } \\
\text { (SCFM) }\end{array}$ & $\begin{array}{c}\text { CALCUL } \\
\text { ATED } \\
\text { RETURN } \\
\text { TIME } \\
\text { FOR } \\
\text { LIQUID } \\
\text { VELOCIT } \\
\text { Y (min) }\end{array}$ & $\begin{array}{c}\text { CALCULAT } \\
\text { ED } \\
\text { RETURN } \\
\text { TIME } \\
\text { FOR } \\
\text { MIXTURE } \\
\text { VELOCITY } \\
\text { (min) }\end{array}$ & $\begin{array}{c}\text { MINIM } \\
\text { UM } \\
\text { EXPERI } \\
\text { MENTA } \\
\text { L } \\
\text { RETUR } \\
\text { N TIME } \\
(\text { min) }\end{array}$ & $\begin{array}{c}\text { MAXIMUM } \\
\text { EXPERIMENT } \\
\text { AL RETURN } \\
\text { TIME (min) }\end{array}$ \\
\hline 1.1 & $60 / 300$ & 25,56 & 11,1 & 20,5 & 24,0 \\
\hline 1.2 & $60 / 500$ & 17,29 & 6,11 & 18,0 & 23,0 \\
\hline 1.3 & $60 / 700$ & 13,23 & 4,05 & 7,0 & 14,0 \\
\hline 1.4 & $100 / 300$ & 13,34 & 9,9 & 14,0 & 15,0 \\
\hline 1.5 & $100 / 500$ & 13,25 & 6,47 & 7,5 & 12,0 \\
\hline 1.6 & $100 / 700$ & 10,80 & 4,67 & 7,5 & 11,0 \\
\hline 1.7 & $100 / 1000$ & 8,60 & 3,29 & 5,0 & 8,0 \\
\hline 1.8 & $100 / 300$ & 15,41 & 11,1 & 15,0 & 16,0 \\
\hline 1.9 & $100 / 700$ & 12,10 & 4,92 & 8,0 & 8,5 \\
\hline 1.10 & $100 / 1000$ & 9,40 & 3,41 & 5,5 & 6,5 \\
\hline
\end{tabular}

Table 13. Experimental and Calculated Results of Solids Return Time - SET2 - 1270m.

\begin{tabular}{|c|c|c|c|c|c|}
\hline TEST & $\begin{array}{l}\text { TESTS } \\
\text { L.F.R } \\
\text { (GPM) } \\
\text { AND } \\
\text { G.F.R } \\
\text { (SCFM) }\end{array}$ & $\begin{array}{l}\text { CALCULATE } \\
\text { D RETURN } \\
\text { TIME } \\
\text { FOR LIQUID } \\
\text { VELOCITY } \\
\text { (min) }\end{array}$ & $\begin{array}{l}\text { CALCULA } \\
\text { TED } \\
\text { RETURN } \\
\text { TIME FOR } \\
\text { MIXTURE } \\
\text { VELOCITY } \\
\text { (min) }\end{array}$ & $\begin{array}{l}\text { MINIMUM } \\
\text { EXPERIME } \\
\text { NTAL } \\
\text { RETURN } \\
\text { TIME } \\
\text { (min) }\end{array}$ & $\begin{array}{c}\text { MAXIMU } \\
\text { M } \\
\text { EXPERIM } \\
\text { ENTAL } \\
\text { RETURN } \\
\text { TIME } \\
\text { (min) }\end{array}$ \\
\hline 2.8 & $60 / 400$ & 55,52 & 25,72 & 63 & 64 \\
\hline 2.9 & $60 / 1000$ & 28,65 & 8,87 & 36 & 38 \\
\hline 2.10 & $100 / 300$ & 40,83 & 24,98 & 42 & 43 \\
\hline 2.11 & $100 / 500$ & 32,46 & 18,40 & 27 & 29 \\
\hline 2.12 & $100 / 700$ & 27,44 & 14,16 & 23 & 24 \\
\hline 2.13 & $100 / 1000$ & 22,59 & 10,32 & 18 & 19 \\
\hline 2.14 & $100 / 700$ & 34,25 & 19,68 & 27 & 29 \\
\hline 2.15 & $100 / 1000$ & 32,04 & 17,65 & 27 & 28 \\
\hline
\end{tabular}

Experimental data were obtained by the accompaniment of sand arrival in the sand monitors and in the acrylic pipe. Experimental time began to be recorded in the stripping operation and finished at the peak of solids arrival. The maximum and minimum values were obtained considering the beginning and the end of the stripping. In most tests, more than one strip was performed and the second tends to be shorter and consequently to generate more precise return time results.

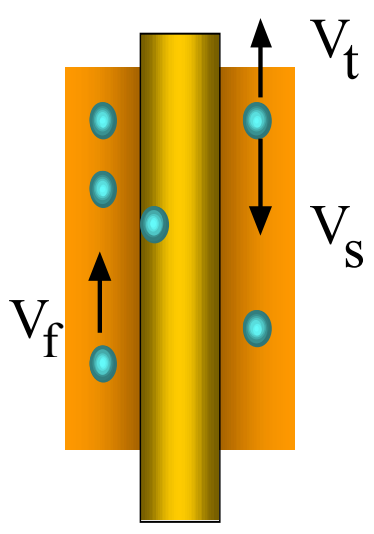

Figure 7. Solids Transport VelocityVertical Wells

\section{A. L. Martins et al. Evaluation of Solids Carrying...}

Figs. 8 and 9 compare graphically the computer simulations and experiments for sets 1 and 2, respectively. In both cases, there is clear tendency of good agreement of the predictions where the effective liquid velocity was used. There is a tendency of overestimation of solids return times in the tests performed with the bigger particles (D2). The mixture velocity concept, on the other hand, tends to over estimate the carrying capacity of the system, resulting in smaller return times.

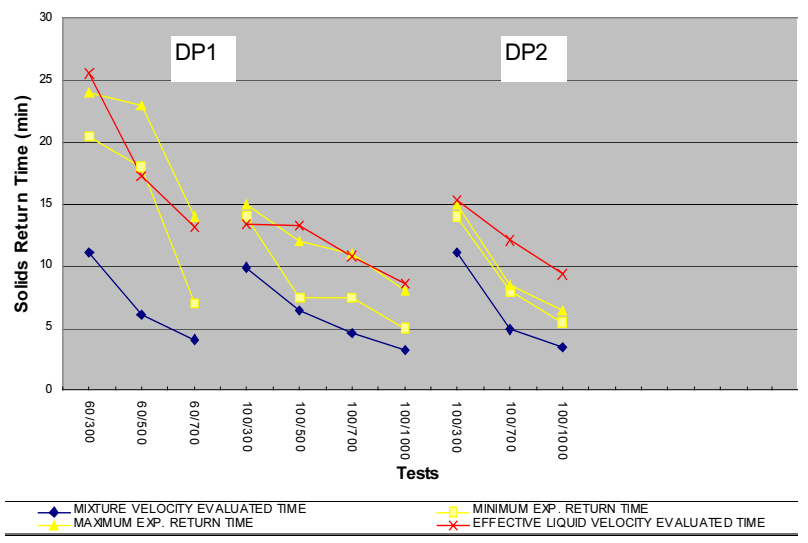

Figure 8. Comparison Between Simulated and Experimental Results - SET 1

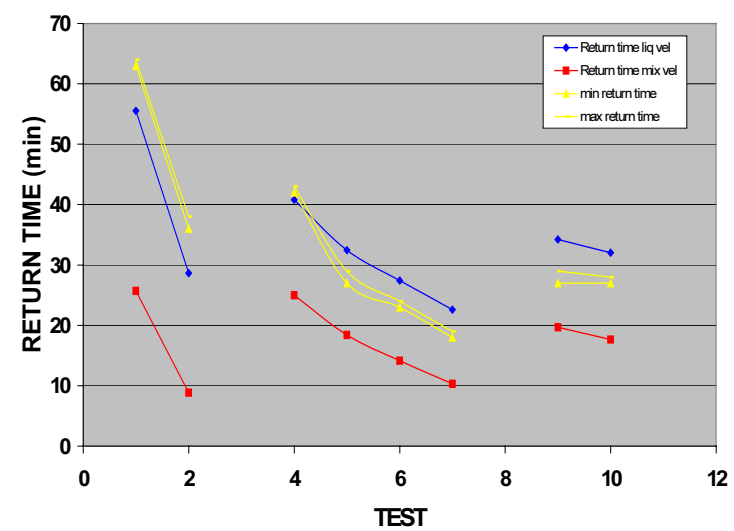

Figure 9. Comparison Between Simulated and Experimental Results - SET 2

\section{Concluding Remarks}

- The influence of liquid and gas flow rates, rheology, backpressure on the transport of solids of two different diameters in a $700 / 1270 \mathrm{~m}$ vertical well was analyzed and discussed.

- The proposed procedures for sedimentation velocity of particles in liquids proved to be adequate for aerated fluids, since the predictions were accurate for both particle sizes.

- Results from set 1 (water, $700 \mathrm{~m}$ depth) indicated the big effect of increasing gas flow rate in the return time of cuttings. The effect of increasing liquid flow rate is 
- bigger at low gas injection rates. Particle diameter, in the range tested, has a minor effect.

- From the observations above, it was possible to state that the proposed mechanism for solids transport by aerated fluids is that the liquid phase is responsible for the carrying capacity of the mixture, while the gas phase is responsible for accelerating the flow, and consequently the total system.

- With the tests performed in set 2 (water, $1270 \mathrm{~m}$ ), it was possible to confirm the experimental indications of set 1 , validating them for another depth.

- For both sets of tests, the concept of effective liquid velocity was considered adequate to simulate the system behavior regarding cuttings transport. There was some tendency of overestimation of solids return time in the tests with bigger particle diameters. This approach, coupled with the proper correlations for sedimentation velocity, was included at PETROBRAS hydraulics software as the method for predicting hole cleaning with aerated fluids in vertical wells.

- Further steps include the evaluation of the nature of the liquid phase (using polymer muds) and of the backpressure.

\section{References}

Adewumi, M.A., Supon S.B., 1989, “An Experimental Study of the Annulus Pressure Drop in a Simulated Air Drilling Operation" - SPE 19334 presented at The SPE Eastern Regional Meeting, Morgantown, USA, 1989.

Guo, B., Hareland, G., Rajtar, J., 1993, "Computer Simulation Predicts Unfavorable Mud Rate and Optimum Air Injection Rate for Aerated Mud Drilling" - SPE 26892 presented at the Eastern Regional Conference and Exhibition, Pittsburgh, PA.

Rommetveit, R., Vefring, E.H., Wang, Z, 1995, "A Dynamic Model for Underbalanced Drilling With Coiled Tubing" - SPE/IADC 29363 presented at The SPE/IADC Drilling Conference, Amsterdam, Holand.

Sá, C.H.M., Martins, A.L., Lourenço, A.M.F., Aguiar, W.B. Jr, 1996, "Wall and Population Effects on The Fall Velocity of Irregularly Shaped Particules In Non-Newtonian Fluids", (in Portuguese). Procedings of the Brazilian Conference on Thermal Sciences, ABCM, Brazil. 